\title{
DIFFUSION APPROXIMATION FOR FIRST OVERFLOW TIME IN GI/G/m SYSTEM WITH FINITE CAPACITY
}

\author{
BONG DAE CHOI and YONG WAN LEE \\ Korea Advanced Institute of Science and Technology \\ Department of Mathematics \\ Gusong-dong, Yusong-gu, Taejon 305-701, KOREA \\ YANG WOO SHIN \\ Changwon National University \\ Department of Statistics \\ 9 Sarimdong, Changwon 641-773, KOREA
}

(Received February, 1994; revised June, 1994)

\begin{abstract}
We present a diffusion approximation of the first overflow time in the $G I / G / m$ system with finite capacity. We derive the Laplace Stieltjes transform of the first passage time of diffusion process which approximates the system size in the $G I / G / m$ system with finite capacity. We use the first passage time of diffusion process as the first overflow time in the $G I / G / m$ system with finite capacity. To check on accuracy of this approximation, the analytical results for the mean of the first overflow time in the $G I / M / m$ system with finite capacity is numerically compared with the diffusion approximation results. Numerical results show that the diffusion approximation is a good approximation for heavy traffic systems.
\end{abstract}

Key words: Diffusion Process, First Passage Time, First Overflow Time.

AMS (MOS) subject classifications: $60 \mathrm{~J} 60,60 \mathrm{~K} 25,90 \mathrm{~B} 22$.

\section{Introduction}

For a single server system, diffusion approximations for the first overflow time in the $G I / G / 1$ system with finite capacity were presented by Kimura et al. [12] and Duda [6]. Kimura et al. [12] analyzed the first overflow time using the backward diffusion equation for the first passage time of diffusion process under the assumption of the exponentially distributed holding time. In the concluding remarks, they mentioned that an extension problem to many server queueing systems is not difficult theoretically, but it becomes difficult to solve the corresponding differential equations because of spatial nonhomogeneity. Duda [6] obtained a diffusion approximation of the first overflow time for the $G I / G / 1 / N-1$ system by using a transient diffusion approximation of the queue size distribution. Recently Choi and Shin [4] obtained a transient diffusion approximation for the queue size distribution in a $G I / G / m$ system using the solution of FokkerPlanck equation, and they [5] also obtained a transient diffusion approximation for the queue size distribution in an $M / G / m$ system with finite capacity. 
In this paper, we deal with the first overflow time for a multi-server system. Following Duda's approach [6] and using our recent results $[4,5]$, we obtain the probability density function of the first passage time in the diffusion process with an elementary return boundary having Cox distribution of holding time as an approximation of the probability density function of the first overflow time in the $G I / G / m / N-1$ system. As an application of the first overflow time, we investigate a transient behavior of the maximal number of customers in the $G I / G / m$ system.

This paper is organized as follows. In Section 2, we find the Laplace Stieltjes transform of the first passage time by using a solution of the Fokker-Planck equation of a diffusion process with an elementary return boundary at $x=0$ and absorbing boundary at $x=N$. Then we use it as an approximation of the first overflow time in the $G I / G / m / N-1$ system. In Section 3 , we present a transient diffusion approximation of the maximal number of customers in the $G I / G / m$ system using the first overflow time. In Section 4, we derive the analytical results for the first overflow time in the $G I / M / m / N-1$ system and numerically compare them for accuracy with the approximation results.

\section{First Overflow Time in $G I / G / m / N-1$ System}

Let $Q(t)$ be the number of customers in a $G I / G / m$ system at time $t$. Given $Q(0)=x_{0}$, the first overflow time in $G I / G / m / N-1$ system, defined by

$$
T\left(x_{0}, N\right)=\inf \left\{t \geq 0 \mid Q(t)=N, Q(0)=x_{0}\right\},
$$

represents the time at which the number of customers first exceeds the capacity. As an approximation of $T\left(x_{0}, N\right)$ we take the first passage time of a diffusion process approximating $Q(t)$. Since the state space of $Q(t)$ is $\{0,1, \ldots, N\}$ when $t \leq T\left(x_{0}, N\right)$, as a diffusion process approximating $Q(t)$ up to $T\left(x_{0}, N\right)$, we take the diffusion process $X(t)$ with state space $[0, N]$ and with elementary return boundary at $x=0$ and absorbing boundary at $x=N$. (For the examples of usages of diffusion process with elementary return boundary, see [3-7], [9-12], etc.) The process $\{X(t), t \geq 0\}$ behaves as follows. When the trajectory of $X(t)$ reaches the boundary $x=0$, it remains there for a random interval of time called a holding time. After the sojourn at the boundary the trajectory jumps into the interior $(0, N)$ and starts from scratch. The holding time at $x=0$ in the diffusion process corresponds to the time interval during which the system is empty in the queueing theoretic context. The first passage time of $X(t)$ to the value $x=N$ is defined by

$$
T_{d}\left(x_{0}, N\right)=\inf \left\{t \geq 0 \mid X(t)=N, X(0)=x_{0}\right\}
$$

and is used as an approximation of the first overflow time $T\left(x_{0}, N\right)$. The remaining part of this section is devoted to the finding the p.d.f. of $T_{d}\left(x_{0}, N\right)$. The diffusion process $X(t)$ is specified by the infinitesimal variance $a(x)$ and infinitesimal mean $b(x)$. By the same reason as in Kimura [11], and Choi and Shin [4], we choose the diffusion parameters as

$$
\begin{gathered}
a(x)=\lambda^{3} \sigma_{a}^{2}+\min (m,\lceil x\rceil) \mu^{3} \sigma_{s}^{2} \\
b(x)=\lambda-\min (m,\lceil x\rceil) \mu,
\end{gathered}
$$

where $[x]$ is the smallest integer greater than or equal to $x$. The mean and variance of the interarrival times are $\frac{1}{\lambda}$ and $\sigma_{a}^{2}$, and the mean and variance of the service times are $\frac{1}{\mu}$ and $\sigma_{s}^{2}$, respectively. We assume that the holding time at $x=0$ has the $n$-stage Cox distribution $[4,6,7$, $9,10]$ with the Laplace Stieltjes transform $h^{*}(s)=\sum_{i=1}^{n}\left(1-c_{i}\right) d_{i} e_{i}^{*}(s)$, where $e_{i}^{*}(s)=\prod_{j=1}^{i}$ $\frac{\lambda_{j}}{s+\lambda_{j}}$ and 


$$
d_{i}=\left\{\begin{array}{cl}
1 & \text { if } i=1 \\
c_{1} c_{2} \ldots c_{i-1} & \text { if } i>1
\end{array}\right.
$$

Then the probability density function $f\left(x, t \mid x_{0}\right)$ of $X(t)$ given $X(0)=x_{0}$, defined by $f\left(x, t \mid x_{0}\right) d x=P\left\{x<X(t) \leq x+d x \mid X(0)=x_{0}\right\}$, satisfies the following Fokker-Planck equation (Feller [8], Gelenbe [10])

$$
\begin{aligned}
& \frac{\partial f}{\partial t}=\frac{1}{2} \frac{\partial^{2}}{\partial x^{2}}\left\{a(x) f\left(x, t \mid x_{0}\right)\right\}-\frac{\partial}{\partial x}\left\{b(x) f\left(x, t \mid x_{0}\right)\right\} \\
& +\sum_{i=1}^{n} \lambda_{i}\left(1-c_{i}\right) P_{i}(t) \delta(x-1), \quad 0<x<N, \quad t \geq 0
\end{aligned}
$$

with the initial and boundary conditions

$$
\begin{gathered}
f\left(x, 0 \mid x_{0}\right)=\delta\left(x-x_{0}\right) \\
f\left(0, t \mid x_{0}\right)=f\left(N, t \mid x_{0}\right)=0 \\
P_{i}(t)=\left\{\begin{array}{cc}
1 & \text { if } x_{0}=0 \text { and } i=1 \\
0 & \text { otherwise }
\end{array}\right. \\
\frac{d P_{i}(t)}{d t}=\left\{\begin{array}{cc}
-\lambda_{1} P_{1}(t)+\lim _{x \downarrow 0} C_{x, t} f & \text { if } i=1 \\
-\lambda_{i} P_{i-1}(t)+\lambda_{i-1} c_{i-1} P_{i-1}(t) & \text { if } 1<i \leq n,
\end{array}\right.
\end{gathered}
$$

where $\delta(\cdot)$ is Dirac's delta function and $P_{i}(t)$ is the probability that the process $X(t)$ is at the $i$ th stage of the Cox distribution on the lower boundary $x=0$ and $C_{x, t} f=\frac{1}{2} \frac{\partial}{\partial x}\left\{a(x) f\left(x, t \mid x_{0}\right)\right\}-$ $b(x) f\left(x, t \mid x_{0}\right)$. Let $a_{k}=a(k), b_{k}=b(k), g_{k}\left(t \mid x_{0}\right)=f\left(k, t \mid x_{0}\right), k=1,2, \ldots, m$ and $f_{k}\left(x, t \mid x_{0}\right)$ be the restriction of $f\left(x, t \mid x_{0}\right)$ on $k-1<x<k, t \geq 0, k=1,2, \ldots, m-1$.

Following the same approaches as that in Choi and Shin [3], the Laplace transform $f^{*}\left(x, s \mid x_{0}\right)$ of the solution $f\left(x, t \mid x_{0}\right)$ of equation (2.2) under conditions (2.3) is given as follows:

$$
\begin{aligned}
& \text { for } k-1<x \leq k, k=1,2, \ldots, m-1 \\
& \qquad \begin{aligned}
f_{k}^{*}\left(x, s \mid x_{0}\right)=\exp \left(\frac{b_{k}}{a_{k}}(x-k)\right) \frac{\sinh A_{k}(x-k+1)}{\sinh A_{k}} g_{k}^{*}\left(s \mid x_{0}\right) \\
\quad-\exp \left(\frac{b_{k}}{a_{k}}(x-k+1)\right) \frac{\sinh A_{k}(x-k)}{\sinh a_{k}} g_{k-1}^{*}\left(s \mid x_{0}\right),
\end{aligned}
\end{aligned}
$$

and for $m-1<x \leq N, t \geq 0$,

$$
\begin{gathered}
f_{m}^{*}\left(x, s \mid x_{0}\right)=\exp \left(\frac{b_{m}}{a_{m}}(x-m+1)\right) \frac{\sinh A_{m}(N-x)}{\sinh A_{m}(N-m+1)} g_{m-1}^{*}\left(s \mid x_{0}\right) \\
+\frac{2}{a_{m} A_{m}} \exp \left(\frac{b_{m}}{a_{m}}\left(x-x_{0}\right)\right)\left(\frac{\sinh A_{m}\left(N-x_{0}\right)}{\sinh A_{m}(N-m+1)} \sinh A_{m}(x-m+1)\right. \\
\left.-\sinh A_{m}\left(x-x_{0}\right) 1\left(x \geq x_{0}\right)\right) 1\left(m-1<x_{0} \leq N\right),
\end{gathered}
$$


where $1(D)$ is the indicator function of $D$ and $A_{k}=\frac{\sqrt{2 a_{k} s+b_{k}^{2}}}{a_{k}}, k=1,2, \ldots, m$. Next we will determine $g_{k}^{*}\left(s \mid x_{0}\right)$ in (2.4) and (2.5) in terms of known parameters like $\lambda, \sigma_{a}^{2}, \mu, \sigma_{b}^{2}$ and $h^{*}(x)$. By applying the Laplace transform to equation $(2.3 d)$ with respect to $t$-variable, we have the following:

$$
\begin{gathered}
{\left[C_{x, s} f^{*}\right]_{x \downarrow 0}=\left(\lambda_{1}+s\right) P_{1}^{*}(s)-P_{1}(0),} \\
P_{i}^{*}(s)=\frac{d_{i}}{\lambda_{i}} e_{i}^{*}(s)\left(\lambda_{1}+s\right) P_{1}^{*}(s), \quad 1<i \leq n,
\end{gathered}
$$

where

$$
C_{x, s} f^{*}=\frac{1}{2} \frac{\partial}{\partial x}\left\{a(x) f^{*}\left(x, s \mid x_{0}\right)\right\}-b(x) f^{*}\left(x, s \mid x_{0}\right) .
$$

Thus, we have from the definition of $h^{*}(s)$ and (2.7) that

$$
\sum_{i=1}^{n} \lambda_{i}\left(1-c_{i}\right) P_{i}^{*}(s)=h^{*}(s)\left(\lambda_{1}+s\right) P_{1}^{*}(s) .
$$

Applying the Laplace transform to equation (2.2) with respect to $t$-variable, then integrating with respect to $x$-variable, and using $(2.8)$ we have that

$$
\begin{gathered}
C_{x, s} f^{*}=\left[C_{x, s} f^{*}\right]_{x \downarrow 0}+s \int_{0}^{x} f^{*}\left(y, s \mid x_{0}\right) d y-1\left(x \geq x_{0}\right) \\
-\left(\lambda_{1}+s\right) P_{1}^{*}(s) h^{*}(s) 1(x \geq 1) .
\end{gathered}
$$

After simple calculations we have from (2.9) that

$$
\begin{gathered}
{\left[C_{x, s} f_{2}^{*}\right]_{x \downarrow 1}=\left[C_{x, s} f_{1}^{*}\right]_{x \uparrow 1}-\left(\lambda_{1}+s\right) P_{1}^{*}(s) h^{*}(s)-1\left(x_{0}=1\right)} \\
{\left[C_{x, s} f_{k}^{*}\right]_{x \downarrow k-1}=\left[C_{x, s} f_{k-1}^{*}\right]_{x \uparrow k-1}-1\left(x_{0}=k-1\right), k=3,4, \ldots, m .}
\end{gathered}
$$

From (2.4), (2.6) and (2.10) we have

$$
\begin{gathered}
\left(\lambda_{1}+s\right) P_{1}^{*}(s)-B_{1} g_{1}^{*}\left(s \mid x_{0}\right)=1\left(x_{0}=0\right) \\
-\left(\lambda_{1}+s\right) P_{1}^{*}(s) h^{*}(s)+C_{2} g_{1}^{*}\left(s \mid x_{0}\right)-B_{2} g_{2}^{*}\left(s \mid x_{0}\right)=1\left(x_{0}=1\right)
\end{gathered}
$$

where

$$
\begin{gathered}
B_{k}=\frac{a_{k} A_{k}}{2} e^{-\frac{b_{k}}{a_{k}} \frac{1}{\sinh A_{k}}, \quad k=1,2,} \\
C_{2}=-\frac{b_{1}}{2}+\frac{a_{1} A_{1}}{2} \frac{\cosh A_{1}}{\sinh A_{1}}+\frac{b_{2}}{2}+\frac{a_{2} A_{2}}{2} \frac{\cosh A_{2}}{\sinh A_{2}} .
\end{gathered}
$$

By eliminating $\left(\lambda_{1}+s\right) P_{1}^{*}(s)$ in $(2.12)$ and $(2.13)$, we have

$$
\left(C_{2}-h^{*}(s) B_{1}\right) g_{1}^{*}\left(s \mid x_{0}\right)-B_{2} g_{2}^{*}\left(s \mid x_{0}\right)=h^{*}(s) 1\left(x_{0}=0\right)+1\left(x_{0}=1\right) .
$$

By following the same procedure as we obtain the above equation for $g_{1}^{*}\left(s \mid x_{0}\right)$ and $g_{2}^{*}\left(s \mid x_{0}\right)$, we can obtain equations in $g_{k}^{*}\left(s \mid x_{0}\right), k=2,3, \ldots, m-1$ from $(2.4),(2.5)$ and (2.11). We omit the detail derivations and we express all equations in $g_{k}^{*}\left(s \mid x_{0}\right)$ in matrix form as following 
tridiagonal system,

$$
T(s) \vec{g}(s)=\vec{v}(s)
$$

where $\vec{g}(s)=\left(g_{1}^{*}(s), g_{2}^{*}(s), \ldots, g_{m-1}^{*}(s)\right)^{t}$ and $T(s)=\operatorname{trid}(\vec{p}(s), \vec{q}(s), \vec{r}(s))$ is the $(m-1) \times(m-1)$ tridiagonal matrix with diagonal vector $\vec{q}(s)=\left(q_{1}(s), q_{2}(s), \ldots, q_{m-1}(s)\right)$, super diagonal vector $\vec{r}(s)=\left(r_{1}(s), r_{2}(s), \ldots, r_{m-2}(s)\right)$ and subdiagonal vector $\vec{p}(s)=\left(p_{2}(s), p_{3}(s), \ldots, p_{m-1}(s)\right)$. The components of $\vec{p}(s), \vec{q}(s)$ and $\vec{r}(s)$ are as follows:

$$
\begin{gathered}
q_{1}(s)=C_{2}-h^{*}(s) B_{1}, \\
q_{k}(s)=C_{k+1}, \quad k=2,3, \ldots, m-2, q_{m-1}(s)=C_{m, N} \\
p_{k}(s)=-B_{k} e^{2 \frac{b_{k}}{a k}}, \quad k=2,3, \ldots, m-1, \\
r_{k}(s)=-B_{k+1}, \quad k=1,2, \ldots, m-2,
\end{gathered}
$$

where $B_{k}, C_{k}, C_{m, N}$ are given by

$$
\begin{gathered}
B_{k}=\frac{a_{k} A_{k}}{2} e^{-\frac{b_{k}}{a_{k}}} \frac{1}{\sinh A_{k}}, k=1,2, \ldots, m-1 \\
C_{k}=-\frac{b_{k-1}}{2}+\frac{a_{k-1} A_{k-1}}{2} \frac{\cosh A_{k-1}}{\sinh A_{k-1}}+\frac{b_{k}}{2}+\frac{a_{k} A_{k}}{2} \frac{\cosh A_{k}}{\sinh A_{k}}, k=2,3, \ldots, m-1 \\
C_{m, N}=-\frac{b_{m-1}}{2}+\frac{a_{m-1} A_{m-1}}{2} \frac{\cosh A_{m-1}}{\sinh A_{m-1}}+\frac{b_{m}}{2}+\frac{a_{m} A_{m}}{2} \frac{\cosh A_{m}(N-m+1)}{\sinh A_{m}(N-m+1)} .
\end{gathered}
$$

The components of the vector $\vec{v}(s)=\left(v_{1}(s), v_{2}(s), \ldots, v_{m-1}(s)\right)^{t}$ are as follows:

$$
\begin{gathered}
v_{1}(s)=h^{*}(s) 1\left(x_{0}=0\right)+1\left(x_{0}=1\right) \\
v_{k}(s)=1\left(x_{0}=k\right), \quad k=2,3, \ldots, m-2, \\
v_{m-1}(s)=e^{\frac{b_{m}}{a_{m}}\left(m-1-x_{0}\right)} \frac{\sinh A_{m}\left(N-x_{0}\right)}{\sinh A_{m}(N-m+1)} 1\left(m-1 \leq x_{0}<N\right) .
\end{gathered}
$$

Note that $A_{k}, B_{k}$ and $C_{k}$ are functions of variable " $s$ ". However, for brevity we use $A_{k}, B_{k}$, $C_{k}$ instead of $A_{k}(s), B_{k}(s), C_{k}(s)$, whenever this will cause no confusion. By solving the simultaneous equation (2.14), we can obtain $g_{k}^{*}\left(s \mid x_{0}\right)$ explicitly.

Remark. From (2.14), (2.15) and (2.16), we see that $g_{k}^{*}\left(s \mid x_{0}\right)$ depends only on the Laplace transform $h^{*}(s)$ of holding time but not on the $P_{i}^{*}(s)$. By the continuity theorem of the Laplace transform and the fact that the set of all Cox distributions is dense in the set of probability on $(0, \infty)$ (Asmussen [1]) $(2.14),(2.15)$ and $(2.16)$ hold true for general distribution of holding time.

The probability density function $f_{t d}\left(t \mid x_{0}, N\right)$ of $T_{d}\left(x_{0}, N\right)$ is obtained as the flow of the probability mass away from $[0, N)$ via the absorbing boundary $x=N$ (Duda [6]), that is,

$$
f_{t d}\left(t \mid x_{0}, N\right)=-\lim _{x \uparrow N}\left[\frac{1}{2} \frac{\partial}{\partial x}\left\{a(x) f\left(x, t \mid x_{0}\right)\right\}-b(x) f\left(x, t \mid x_{0}\right)\right] .
$$


Thus from (2.5) and (2.17) we have the following theorem.

Theorem 1. The Laplace transform $f_{t d}^{*}\left(s \mid x_{0}, N\right)$ of $f_{t d}\left(t \mid x_{0}, N\right)$ is given by

$$
\begin{gathered}
f_{t d}^{*}\left(s \mid x_{0}, N\right)=g_{m-1}^{*}\left(s \mid x_{0}\right) \frac{a_{m} A_{m}}{2} \exp \left(\frac{b_{m}}{a_{m}}(N-m+1)\right) \frac{1}{\sinh A_{m}(N-m+1)} \\
+e^{\frac{b_{m}}{a}\left(N-x_{0}\right)} \frac{\sinh A_{m}\left(x_{0}-m+1\right)}{\sinh A_{m}(N-m+1)} 1\left(m-1 \leq x_{0}<N\right) .
\end{gathered}
$$

Remark. An explicit expression of the inverse Laplace transform $f_{t d}\left(t \mid x_{0}, N\right)$ of $f_{t d}^{*}\left(s \mid x_{0}, N\right)$ does not seem to be accomplishable. Instead, there are many algorithms available for the numerical inversion of Laplace transforms. For example, there are three standard routines currently available from the ACM library of software algorithms: Algorithm 368 (Stehfest [14]); Algorithm 486 (Veillon [15]); Algorithm 619 (Piessens and Huysmana [13]).

By differentiating $f_{t d}^{*}\left(s \mid x_{0}, N\right)$ at $s=0$ we obtain the mean of $T_{d}\left(x_{0}, N\right)$.

Corollary 2. When $b_{m}=\lambda-m \mu \neq 0$,

$$
\begin{gathered}
E\left(T_{d}\left(x_{0}, N\right)\right)=-\frac{\exp \left(\frac{b_{m}}{a_{m}}(N-m+1)\right)}{2 b_{m}\left(\sinh \frac{b_{m}}{a_{m}}(N-m+1)\right)^{2}}(I+I I) \\
-\frac{\exp \left(\frac{b_{m}}{a_{m}}\left(N-x_{0}\right)\right)}{b_{m}\left(\sinh \frac{b_{m}}{a_{m}}(N-m+1)\right)^{2}}(I I I-I V),
\end{gathered}
$$

where

$$
\begin{gathered}
I=g_{m-1}^{*^{\prime}}(0) b_{m}^{2} \sinh \frac{b_{m}}{a_{m}}(N-m+1) \\
I I=g_{m-1}^{*}(0)\left(a_{m} \sinh \frac{b_{m}}{a_{m}}(N-m+1)-b_{m}(N-m+1) \cosh \frac{b_{m}}{a_{m}}(N-m+1)\right), \\
\left.I I I=\left(x_{0}-m+1\right) \cosh \frac{b_{m}}{a_{m}}\left(x_{0}-m+1\right) \sinh \frac{b_{m}}{a_{m}}(N-m+1) 1(m-1) \leq x_{0}<N\right), \\
I V=(N-m+1) \sinh \left(\frac{b_{m}}{a_{m}}\left(x_{0}-m+1\right)\right) \cosh \frac{b_{m}}{a_{m}}(N-m+1) 1\left(m-1 \leq x_{0}<N\right) .
\end{gathered}
$$

When $b_{m}=\lambda-m \mu=0$,

$$
\begin{gathered}
E\left(T_{d}\left(x_{0}, N\right)\right)=\frac{3 a_{m} g_{m-1}^{*^{\prime}}(0)-(N-m+1)^{2} g_{m-1}^{*}(0)}{6(N-m+1)} \\
+\frac{\left(x_{0}-m+1\right)\left(N-x_{0}\right)\left(N+x_{0}-2(m-1)\right)}{3 a_{m}(N-m+1)} 1\left(m-1 \leq x_{0}<N\right) .
\end{gathered}
$$

\section{Maximal Number of Customers}

The maximal number of customers in the $G I / G / m$ system up to the time $t \geq 0$ is defined in 
$[12]$ as

$$
M\left(t \mid x_{0}\right)=\sup _{0<u<t}\left\{Q(u) \mid Q(0)=x_{0}\right\} .
$$

Let $M_{d}\left(t \mid x_{0}\right)$ denote the diffusion approximation of $M\left(t \mid x_{0}\right)$. Using the following relation

$$
\left\{M_{d}\left(t \mid x_{0}\right) \leq n\right\}=\left\{T_{d}\left(x_{0}, n\right) \geq t\right\},
$$

we obtain the distribution of $M_{d}\left(t \mid x_{0}\right)$ as follows

$$
F_{m_{d}}\left(t, n \mid x_{0}\right)=P\left(M_{d}\left(t \mid x_{0}\right) \leq n\right)=1-F_{t_{d}}\left(t \mid x_{0}, n\right),
$$

where $F_{t_{d}}\left(t \mid x_{0}, n\right)$ is the distribution function of $T_{d}\left(x_{0}, n\right)$. Thus the Laplace transform of $F_{m_{d}}\left(t, n \mid x_{0}\right)$ with respect to $t$ variable has form

$$
F_{t_{d}}^{*}\left(s, n \mid x_{0}\right)=\frac{1}{s}\left(1-f_{t_{d}}^{*}\left(s \mid x_{0}, n\right)\right) .
$$

The Laplace transform of the mean maximal number of customers is

$$
\int_{0}^{\infty} e^{-s t} E\left(M_{d}\left(t \mid x_{0}\right)\right) d t=\frac{1}{s}\left(x_{0}+\sum_{n=x_{0}}^{\infty} f_{t_{d}}^{*}\left(s \mid x_{0}, n\right)\right) .
$$

\section{Numerical Examples}

In order to examine the accuracy of the diffusion approximation we numerically compare the approximate results obtained in Section 2 with analytical results. It is impossible to obtain the exact probability density function of the first overflow time for the $G I / G / m / N-1$ system. However, for the case that the service time distribution is exponential, that is, for the $G I / M / m / N-1$ system, the analytical results of the first overflow time can be obtained. Following the procedure in Kimura et al. [12], we have the following theorems for $G I / M / m / N-1$ system and we will omit their proofs.

Theorem 3. Let $\left\{\phi_{j}(s): j=0,1,2, \ldots, N-2\right\}$ be the solution of the following linear system

$$
\phi_{i}(s)=q_{i, N-1}^{*}(s)+\sum_{j=0}^{N-2} q_{i, j}^{*}(s) \phi_{j}(s), \quad i=0,1,2, \ldots, N-2,
$$

where $q_{i, j}^{*}(s)=\int_{0}^{\infty} e^{-s t} q_{i j}(t) d F(t)$, and $F(t)$ is the probability distribution of interarrival times

$$
q_{i j}(t)=\left\{\begin{array}{cc}
0 & \text { if } j>i+1, \\
\left(\begin{array}{c}
i+1 \\
i+1-j
\end{array}\right)\left(1-e^{-\mu t}\right)^{i+1-j} & \text { if } j \leq i+1 \leq m, \\
\left(\begin{array}{c}
m \\
m-j
\end{array}\right) \frac{(m \mu)^{i-m+1}}{(i-m) !} \int_{0}^{t}\left(1-e^{\mu(t-x)}\right) e^{\mu(t-x) j} x^{i-m} e^{-m \mu x} d x & \text { if } j<m<i+1, \\
\frac{e^{m \mu t}(m \mu t)^{i+1-j}}{(i+1-j) !} & \text { if } m \leq j \leq i+1 .
\end{array}\right.
$$


Then the Laplace Stieltjes transform of the distribution of the first overflow time for the $G I / M / m / N-1$ system is given by

$$
f^{*}(s \mid i, N)=\pi_{i, N-1}(s)+\sum_{j=0}^{N-2} \pi_{i, j}(s) \phi_{j}(s),
$$

where

$$
\pi_{i j}(s)=\left\{\begin{array}{cc}
\int_{0}^{\infty} e^{-s t} \delta_{0 j} d F_{0}(t) & \text { for } i=0 \\
q_{i-1, j}^{*}(s) & \text { for } i \neq 0
\end{array}\right.
$$

where $\delta_{i j}$ denotes Kronecker's delta and $F_{0}(t)$ is the probability distribution of the first arrival time.

By differentiating the both sides of (4.1), we have the following theorem for $\bar{\phi}_{i}=-\left.\frac{d \phi_{i}}{d s}\right|_{s=0}$.

Theorem 4. Let $\left\{\bar{\phi}_{j}, j=0,1,2, \ldots, N-2\right\}$ be the solution of the following linear system

$$
\bar{\phi}_{i}=\frac{1}{\lambda}+\sum_{j=0}^{N-2} q_{i j}^{*}(0) \bar{\phi}_{j}, \quad i=0,1,2, \ldots, N-2 .
$$

Then the mean value of the first overflow time for the $G I / M / m / N-1$ system is given by

where $\nu_{1}=\int_{0}^{\infty} x d F_{0}(x)$.

$$
E(T(i, N))=\nu_{1}+\sum_{j=0}^{N-2} \pi_{i j}(0) \bar{\phi}_{j}
$$

\section{Calculation procedure of $E\left(T_{d}\left(x_{0}, N\right)\right)$}

To calculate the mean $E\left(T_{d}\left(x_{0}, N\right)\right)$ of the first passage time from Corollary 2, we need to find $g_{m-1}^{*}(0)$ and $g_{m-1}^{*^{\prime}}(0)=\left.\frac{d g_{m-1}^{*}\left(s \mid x_{0}\right)}{d s}\right|_{s=0}$. The procedure of finding $g_{m-1}^{*}(0)$ and $g_{m-1}^{*^{\prime}}(0)$ is as follows.

1. To find $\vec{g}(0)$, solve tridiagonal system $(2.14)$ at $s=0$,

$$
T(0) \vec{g}(0)=\vec{v}(0) .
$$

2. To find $\vec{g}^{\prime}(0)$, solve the system

$$
T(0) \vec{g}^{\prime}(0)=\vec{v}^{\prime}(0)-T^{\prime}(0) \vec{g}(0) .
$$

A simple calculation gives the components of $T(0), \vec{g}(0)$ and $\vec{v}(0)$ as follows:

$$
\begin{gathered}
q_{1}(0)=B_{2}(0) e^{2 \frac{b_{2}}{a_{2}}}, q_{k}(0)=C_{k+1}(0), k=2,3, \ldots, m-2, q_{m-1}(0)=C_{m, N}(0) \\
p_{k}(0)=-B_{k}(0) e^{2 \frac{b_{k}}{a} k}, k=2,3, \ldots, m-1 \\
r_{k}(0)=-B_{k+1}(0), k=1,2, \ldots, m-2 \\
v_{1}(0)=1\left(x_{0}=0\right)+1\left(x_{0}=1\right), v_{k}(0)=1\left(x_{0}=k\right), k=2,3, \ldots, m-2
\end{gathered}
$$




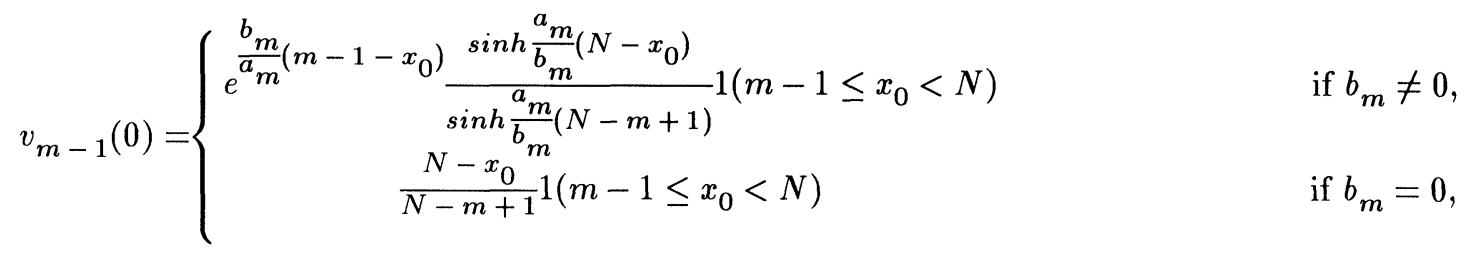

where

$$
\begin{aligned}
& B_{k}(0)=\left\{\begin{array}{cc}
\frac{b_{k}}{\left.\exp ^{b} \frac{k}{a_{k}}\right)-1} & \text { if } b_{k} \neq 0, k=1,2, \ldots, m-1, \\
-\frac{a k}{2} & \text { if } b_{k}=0
\end{array}\right. \\
& C_{k}(0)=B_{k-1}(0)+B_{k}(0) e^{2 \frac{b}{a} k}, k=2,3, \ldots, m-1 \\
& B_{m}(0)=\left\{\begin{array}{cc}
\frac{b_{m}}{\exp \left(2 \frac{b_{m}}{a_{m}}(N-m+1)\right)-1} & \text { if } b_{m} \neq 0 \\
\frac{a_{m}}{2(N-m+1)} & \text { if } b_{m}=0
\end{array}\right. \\
& C_{m, N}(0)=B_{m-1}(0)+B_{m}(0) e^{2 \frac{b}{a} m}(N-m+1)
\end{aligned}
$$

The components of $T^{\prime}(0), \vec{g}^{\prime}(0)$ and $\vec{v}^{\prime}(0)$ are as follows:

$$
\begin{aligned}
& q_{1}^{\prime}(0)=C_{2}^{\prime}(0)+\frac{1}{\lambda} B_{1}(0)-B_{1}^{\prime}(0), \\
& q_{k}^{\prime}(0)=C_{k+1}^{\prime}(0), k=2,3, \ldots, m-2, q_{m-1}^{\prime}(0)=C_{m, N}^{\prime}(0) \\
& p_{k}^{\prime}(0)=-B_{k}^{\prime}(0) e^{2 \frac{b}{a} k}, \quad k=2,3, \ldots, m-1 \\
& r_{k}^{\prime}(0)=-B_{k+1}^{\prime}(0), k=1,2, \ldots, m-2, \\
& v_{1}^{\prime}(0)=-\frac{1}{\lambda} 1\left(x_{0}=0\right), v_{k}^{\prime}(0)=0, k=2,3, \ldots, m-2, \\
& v_{m-1}^{\prime}(0)= \begin{cases}e^{\frac{b_{m}}{a}\left(m-1-x_{0}\right)} \frac{V}{2 b_{m}\left(\sinh \frac{{ }^{a} m}{b_{m}}(N-m+1)\right)^{2}} & \text { if } b_{m} \neq 0, m-1 \leq x_{0}<N \\
\frac{1}{6 a_{m}} \frac{\left(2 N-x_{0}-m+1\right)\left(x_{0}-m+1\left(x_{0}-N\right)\right.}{N-m+1} & \text { if } b_{m}=0, m-1 \leq x_{0}<N,\end{cases}
\end{aligned}
$$


where

$$
V=\left(2 N-x_{0}-m+1\right) \sinh \frac{a_{m}}{b_{m}}\left(x_{0}-m+1\right)-\left(x_{0}-m+1\right) \sinh \frac{b_{m}}{a_{m}}\left(2 N-x_{0}-m+1\right),
$$

and

$$
\begin{aligned}
& B_{k}^{\prime}(0)=\left\{\begin{array}{cl}
\frac{1}{b_{k}} \frac{\left(a_{k}-b_{k}\right) e^{2 \frac{b}{a} k}-\left(a_{k}-b_{k}\right)}{\left(\exp \left(2 \frac{b_{k}}{a}\right)-1\right)^{2}} & \text { if } b_{k} \neq 0, \\
-\frac{1}{6} & \text { if } b_{k}=0,
\end{array} \quad k=1,2, \ldots, m-1\right. \\
& C_{k}^{\prime}(0)=X_{k-1}(0)+X_{k}(0), \quad k=2,3, \ldots, m-1, \\
& C_{m, N}^{\prime}(0)=X_{m-1}(0)+X_{m}(0), \\
& X_{k}(0)=\left\{\begin{array}{cl}
\frac{1}{4 b_{k}} \frac{{ }^{a}{ }_{k} \sinh \frac{2 b_{k}}{a_{k}}-2 b_{k}}{\left(\sinh \frac{b_{k}}{a_{k}}\right)^{2}} & \text { if } b_{k} \neq 0, \\
\frac{2}{3 a_{k}} & \text { if } b_{k}=0,
\end{array} \quad k=1,2, \ldots, m-1,\right. \\
& X_{m}(0)=\left\{\begin{array}{cl}
\frac{1}{4 b_{m}} \frac{{ }^{a}{ }_{m} \sinh \frac{2 b_{m}}{a_{m}}(N-m+1)-2 b_{m}(N-m+1)}{\left(\sinh \frac{b_{m}}{a_{m}}(N-m+1)\right)^{2}} & \text { if } b_{m} \neq 0, \\
\frac{2}{3 a_{m}}(N-m+1) & \text { if } b_{k}=0 .
\end{array}\right.
\end{aligned}
$$

In Tables 1-6, we use three types of interarrival time distributions: exponential distribution (denoted by " $M$ "), Erlang distribution of order 2 (denoted by " $E_{2}$ ") and hyperexponential distribution of order 2 (denoted by " $\mathrm{H}_{2}$ "). We assume that $F(t)=F_{0}(t)$. The service time distribution is exponential with mean $\frac{1}{\mu}=1.0$. In the tables, $\rho$ denotes the traffic intensity $\rho=\frac{\lambda}{m \mu}$. The probability density functions for the interarrival times are

$$
\begin{gathered}
M: a(t)=\lambda e^{-\lambda t}, t>0 \\
E_{2}: a(t)=\beta^{2} t e^{-\beta t}, t>0, \beta=2 \lambda \\
H_{2}: a(t)=p_{1} \beta_{1} e^{-\beta_{1} t}+p_{2} \beta_{2} e^{-\beta_{2} t}, t>0,
\end{gathered}
$$

where $\lambda=m \rho, p_{1}=0.5(1.0+\sqrt{0.2}), p_{2}=1-p_{1}, \beta_{1}=2 p_{1} \lambda$ and $\beta_{2}=2 p_{2} \lambda$.

Simple calculations give the explicit expression $q_{i j}^{*}(s)$ as follows.

Case 1. $a(t)=\lambda e^{-\lambda t}, t>0$ 
$q_{i j}^{*}(s)=\left\{\begin{array}{cc}0 & \text { if } j>i+1, \\ \lambda \sum_{k=0}^{i+1-j}(-1)^{k\left(\begin{array}{c}i+1 \\ j, k\end{array}\right) \frac{1}{s+\mu(k+j)+\lambda}} & \text { if } j \leq i+1 \leq m, \\ \lambda\left(\frac{m \mu}{\lambda+s+m \mu}\right)^{i-m+1 \sum_{k=0}^{m-j}(-1)^{k}\left(\begin{array}{c}m \\ k, j\end{array}\right) \frac{1}{\lambda+s+\mu(k+j)}} & \text { if } j<m<i+1, \\ \frac{\lambda(m \mu)^{i+1-j}}{(\lambda+s+m \mu)^{i+2-j}} & \text { if } m \leq j \leq i+1,\end{array}\right.$

where $\left(\begin{array}{c}i+1 \\ j, k\end{array}\right)=\frac{i !}{j ! k !}$

Case 2. $a(t)=\beta^{2} t e^{-\beta t}, t>0$

$$
q_{i j}^{*}(s)=\left\{\begin{array}{cc}
0 & \text { if } j>i+1, \\
\beta^{2} \sum_{k=0}^{i+1-j}(-1)^{k}\left(\begin{array}{c}
i+1 \\
j, k
\end{array}\right) \frac{1}{(s+\mu(k+j)+\beta)^{2}} & \text { if } j \leq i+1 \leq m, \\
\beta\left(\frac{m \mu}{\beta+s+m \mu}\right)^{i-m+1} \sum_{k=0}^{m-j}(-1)^{k}\left(\begin{array}{c}
m \\
k, j
\end{array}\right)\left(\frac{1}{\beta+s+\mu(k+j)}\right)^{2} & \text { if } j<m<i+1, \\
\frac{\beta^{2}(i+2-j)(m \mu)^{i+1-j}}{(\beta+s+m \mu)^{i+3-j}} & \text { if } m \leq j \leq i+1 .
\end{array}\right.
$$

Case 3. $a(t)=p_{1} \beta_{1} e^{-\beta_{1} t}+p_{2} \beta_{2} e^{-\beta_{2} t}, t>0$

$$
q_{i j}^{*}(s)=p_{1} q_{i j}^{*}\left(s, \beta_{1}\right)+p_{2} q_{i j}^{*}\left(s, \beta_{2}\right)
$$

where $q_{i j}^{*}(s, c)$ is obtained by replacing $\lambda$ with $c$ in $q_{i j}^{*}(s)$ of Case 1 .

For the diffusion approximation, we need to approximate the idle period distribution which is not known for $G I / G / m$ system. Heuristic approximations for the distribution of an idle period in the $G I / G / m$ system were proposed in Choi and Shin [4]. It was shown by simulation that $h_{0}(t)=a(t)$ (interarrival time distribution) gives the most accurate result. In this paper, we take $h_{0}(t)=a(t)$ as an approximation of the distribution of an idle period. The "relative percentage errors" (denoted by "ERR") are calculated by the formula

$$
\mathrm{ERR}=\frac{\text { exact value }- \text { approximate value }}{\text { exact value }} \times 100(\%) .
$$

The tables deal with the case $\rho \geq 0.7$. When the relative percentage error is greater than $50 \%$, we use the notation ' $* * * * *$ ' instead of numerical results, since the numerical results are meaningless. We see that the diffusion approximation performs better for the exponential distribution of interarrival time than other distributions. From the tables, we can learn that the accuracy of the diffusion approximation yields the following properties with respect to the mean. The greater traffic intensity $\rho$ is, the more accurate the diffusion approximation is. In particular, if $\rho$ is extremely high $(\rho \geq 0.90)$, then the approximation is quite accurate. When the system capacity is small or the number of servers is large, the tables show that diffusion approximation is still 
good for even moderate traffic $\rho$.

\section{Acknowledgement}

This paper was supported (in part) by NON DIRECTED RESEARCH FUND, Korea Research Foundation, 1991. Authors would like to express their gratitude to the editor and referee whose many insightful suggestions have considerably enhanced the presentation of this paper.

\section{References}

[1] Asmussen, S., Applied Probability and Queues, John Wiley \& Sons, 1987.

[2] Cox, D.R. and Miller, H.D., The Theory of Stochastic Processes, Chapman and Hall, 1965.

[3] Choi, B.D. and Shin, Y.W., Transient diffusion approximation for $M / G / m$ system, $J$. Oper. Res. Soc. Japan, 34:3 (1991), 306-328.

[4] Choi, B.D. and Shin, Y.W., Approximation analysis of time dependent queue size distribution for $G I / G / m$ system using diffusion process, Proc. of KAIST Mathematics Workshop, 6, Analysis and Geometry, edited by B.D. Choi and J.W. Yim, KAIST, Taejeon, Korea (1991), 225-242.

[5] Choi, B.D. and Shin, Y.W., Diffusion approximation for time dependent queue size distribution in $M / G / m / N$ system, preprint.

[6] Duda, A., Transient diffusion approximation for some queueing systems, Performance Evaluation Rev., 12 (1983), 118-128.

[7] Duda, A., Diffusion approximation for time-dependent queueing systems, IEEE Journals on Selected Areas in Communications, SAC4:6 (1986), 905-918.

[8] Feller, W., Diffusion process in one dimension, Trans. Amer. Math. Soc., 77 (1954), 1-31.

[9] Gelenbe, E., On approximate computer system models, J. Ass. Comp. Mach., 22:2 (1975), 261-269.

[10] Gelenbe, E., Probabilistic models of computer systems Part II: Diffusion approximations, waiting times and batch arrivals, Acta Informatica, 12 (1979), 285-303.

[11] Kimura, T., Diffusion approximation for $M / G / m$ queue, Oper. Res., 31:2 (1983), 304-321.

[12] Kimura, T., Ohno, K., and Mine, H., Diffusion approximation for $G I / G / 1$ queueing systems with finite capacity: I - The first overflow time, J. Oper. Res. Soc. Japan, 22:1 (1979), 41-68.

[13] Piessens, R. and Huysmans, R., Algorithm 619. Automatic numerical inversion of the Laplace transform, ACM Trans. Math. Softw., 10 (1984), 348-353.

[14] Stehfest, H., Algorithm 386. Numerical inversion of Laplace transforms, Comm. ACM, 13:1, (1970), 47-49 (erratum 13,624).

[15] Veillon, F., Algorithm 486. Numerical inversion of Laplace transforms, Comm. ACM, 17 (1974), 587-589. 
TABLE 1

Mean of First Overflow Time for $M / M / 3 / N-1$ System

\begin{tabular}{|c|c|c|c|c|c|c|c|}
\hline \multicolumn{2}{|c|}{$N$} & \multicolumn{3}{|c|}{11} & \multicolumn{3}{|c|}{41} \\
\hline$\rho$ & $\begin{array}{c}x_{0} \\
\text { mean }\end{array}$ & 0 & 5 & 10 & 0 & 20 & 40 \\
\hline 0.70 & $\begin{array}{c}\text { TA } \\
\text { TD } \\
\text { ERR }\end{array}$ & $\begin{array}{r}116.41 \\
111.40 \\
4.30\end{array}$ & $\begin{array}{r}108.47 \\
103.70 \\
4.40\end{array}$ & $\begin{array}{r}38.04 \\
36.20 \\
4.83\end{array}$ & $\begin{array}{r}7405535.73 \\
4976645.35 \\
32.80\end{array}$ & $\begin{array}{r}7401437.24 \\
4973662.98 \\
32.80\end{array}$ & $\begin{array}{r}2221680.87 \\
1479975.28 \\
33.38\end{array}$ \\
\hline 0.75 & $\begin{array}{r}\text { TA } \\
\text { TD } \\
\text { ERR }\end{array}$ & $\begin{array}{r}75.87 \\
73.80 \\
2.73\end{array}$ & $\begin{array}{r}69.13 \\
67.21 \\
2.78\end{array}$ & $\begin{array}{r}22.12 \\
21.46 \\
2.99\end{array}$ & $\begin{array}{r}542841.65 \\
484155.52 \\
10.81\end{array}$ & $\begin{array}{r}541582.36 \\
482985.21 \\
10.82\end{array}$ & $\begin{array}{r}135724.44 \\
120336.71 \\
11.34\end{array}$ \\
\hline 0.80 & $\begin{array}{c}\text { TA } \\
\text { TD } \\
\text { ERR }\end{array}$ & $\begin{array}{r}52.45 \\
51.54 \\
1.74\end{array}$ & $\begin{array}{r}46.63 \\
45.82 \\
1.74\end{array}$ & $\begin{array}{r}13.68 \\
13.44 \\
1.79\end{array}$ & $\begin{array}{r}61612.08 \\
59487.26 \\
3.45\end{array}$ & $\begin{array}{r}61082.13 \\
58966.43 \\
3.46\end{array}$ & $\begin{array}{r}12335.52 \\
11866.71 \\
3.80\end{array}$ \\
\hline 0.85 & $\begin{array}{c}\text { TA } \\
\text { TD } \\
\text { ERR }\end{array}$ & $\begin{array}{r}38.14 \\
37.71 \\
1.12\end{array}$ & $\begin{array}{r}33.03 \\
32.67 \\
1.08\end{array}$ & $\begin{array}{l}8.94 \\
8.85 \\
1.05\end{array}$ & $\begin{array}{r}9652.05 \\
9486.15 \\
1.72\end{array}$ & $\begin{array}{r}9386.97 \\
9224.11 \\
1.74\end{array}$ & $\begin{array}{r}1461.03 \\
1433.23 \\
1.90\end{array}$ \\
\hline 0.90 & $\begin{array}{l}\mathrm{TA} \\
\mathrm{TD} \\
\mathrm{ER}\end{array}$ & $\begin{array}{r}28.93 \\
28.72 \\
.75\end{array}$ & $\begin{array}{r}24.41 \\
24.24 \\
.69\end{array}$ & $\begin{array}{r}6.14 \\
6.11 \\
.62\end{array}$ & $\begin{array}{r}2069.84 \\
2056.42 \\
.65\end{array}$ & $\begin{array}{r}1921.05 \\
1908.53 \\
.65\end{array}$ & $\begin{array}{r}220.23 \\
218.69 \\
.70\end{array}$ \\
\hline 0.95 & $\begin{array}{c}\text { TA } \\
\text { TD } \\
\text { ERR }\end{array}$ & $\begin{array}{r}22.76 \\
22.63 \\
.54\end{array}$ & $\begin{array}{r}18.70 \\
18.61 \\
.46\end{array}$ & $\begin{array}{r}4.41 \\
4.40 \\
.37\end{array}$ & $\begin{array}{r}633.57 \\
632.02 \\
.24\end{array}$ & $\begin{array}{r}540.81 \\
539.60 \\
.22\end{array}$ & $\begin{array}{r}45.95 \\
44.86 \\
.22\end{array}$ \\
\hline 1.05 & $\begin{array}{c}\text { TA } \\
\text { TD } \\
\text { ERR }\end{array}$ & $\begin{array}{r}15.33 \\
15.28 \\
.34\end{array}$ & $\begin{array}{r}11.99 \\
11.96 \\
.26\end{array}$ & $\begin{array}{c}2.55 \\
2.54 \\
.18\end{array}$ & $\begin{array}{r}152.03 \\
151.90 \\
.09\end{array}$ & $\begin{array}{r}105.97 \\
105.92 \\
.04\end{array}$ & $\begin{array}{r}5.71 \\
5.71 \\
.02\end{array}$ \\
\hline 1.50 & $\begin{array}{c}\text { TA } \\
\text { TDD } \\
\text { ERR }\end{array}$ & $\begin{array}{r}5.55 \\
5.53 \\
.24\end{array}$ & $\begin{array}{r}3.74 \\
3 / 83 \\
.20\end{array}$ & $\begin{array}{l}.65 \\
.65 \\
.09\end{array}$ & $\begin{array}{r}25.52 \\
25.51 \\
.06\end{array}$ & $\begin{array}{r}14.00 \\
14.00 \\
.00\end{array}$ & $\begin{array}{l}.67 \\
.67 \\
.00\end{array}$ \\
\hline
\end{tabular}


TABLE 2

Mean of First Overflow Time for $M / M / 7 / N-1$ System

\begin{tabular}{|c|c|c|c|c|c|c|c|}
\hline \multicolumn{2}{|c|}{$N$} & \multicolumn{3}{|c|}{11} & \multicolumn{3}{|c|}{41} \\
\hline$\rho$ & $\begin{array}{c}x_{0} \\
\text { mean }\end{array}$ & 0 & 5 & 10 & 0 & 20 & 40 \\
\hline 0.70 & $\begin{array}{c}\text { TA } \\
\text { TD } \\
\text { ERR }\end{array}$ & $\begin{array}{r}18.31 \\
17.82 \\
2.68\end{array}$ & $\begin{array}{r}16.64 \\
16.16 \\
2.90\end{array}$ & $\begin{array}{l}6.12 \\
5.92 \\
3.31 \\
\end{array}$ & $\begin{array}{r}1055817.68 \\
852603.92 \\
20.00\end{array}$ & $\begin{array}{r}1065232.98 \\
852096.81 \\
20.01\end{array}$ & $\begin{array}{r}319751.84 \\
253553.47 \\
20.70\end{array}$ \\
\hline 0.75 & $\begin{array}{c}\text { TA } \\
\text { TD } \\
\text { ERR }\end{array}$ & $\begin{array}{r}13.50 \\
13.27 \\
1.72\end{array}$ & $\begin{array}{r}12.00 \\
11.77 \\
1.90\end{array}$ & $\begin{array}{l}4.09 \\
4.01 \\
2.09\end{array}$ & $\begin{array}{r}105907.78 \\
97246.24 \\
8.18\end{array}$ & $\begin{array}{r}105666.46 \\
97015.44 \\
8.19\end{array}$ & $\begin{array}{r}26482.10 \\
24172.87 \\
8.72\end{array}$ \\
\hline 0.80 & $\begin{array}{c}\text { TA } \\
\text { TD } \\
\text { ERR }\end{array}$ & $\begin{array}{r}10.39 \\
10.28 \\
1.11\end{array}$ & $\begin{array}{l}9.03 \\
8.92 \\
1.24\end{array}$ & $\begin{array}{l}2.87 \\
2.84 \\
1.30\end{array}$ & $\begin{array}{r}14491.27 \\
13975.55 \\
3.56\end{array}$ & $\begin{array}{r}14371.37 \\
13857.83 \\
3.57\end{array}$ & $\begin{array}{r}2903.35 \\
2789.86 \\
3.91\end{array}$ \\
\hline 0.85 & $\begin{array}{r}\mathrm{TA} \\
\mathrm{TD} \\
\mathrm{ERR} \\
\end{array}$ & $\begin{array}{r}8.29 \\
8.23 \\
.72 \\
\end{array}$ & $\begin{array}{r}7.04 \\
6.99 \\
.82 \\
\end{array}$ & $\begin{array}{r}2.10 \\
2.09 \\
.79 \\
\end{array}$ & $\begin{array}{r}2628.89 \\
2591.87 \\
1.41 \\
\end{array}$ & $\begin{array}{r}2561.60 \\
2525.13 \\
1.42 \\
\end{array}$ & $\begin{array}{r}399.48 \\
393.13 \\
1.59 \\
\end{array}$ \\
\hline 0.90 & $\begin{array}{c}\text { TA } \\
\text { TD } \\
\text { ERR }\end{array}$ & $\begin{array}{r}6.81 \\
6.77 \\
.48\end{array}$ & $\begin{array}{r}5.66 \\
5.63 \\
.55\end{array}$ & $\begin{array}{r}1.60 \\
1.59 \\
.48\end{array}$ & $\begin{array}{r}647.13 \\
643.89 \\
.50\end{array}$ & $\begin{array}{r}605.36 \\
602.30 \\
.51 \\
\end{array}$ & $\begin{array}{r}69.91 \\
69.53 \\
.56\end{array}$ \\
\hline 0.95 & $\begin{array}{c}\text { TA } \\
\text { TD } \\
\text { ERR }\end{array}$ & $\begin{array}{r}5.72 \\
5.71 \\
.33\end{array}$ & $\begin{array}{r}4.66 \\
4.64 \\
.38\end{array}$ & $\begin{array}{r}1.25 \\
1.24 \\
.30\end{array}$ & $\begin{array}{r}220.43 \\
220.08 \\
.16\end{array}$ & $\begin{array}{r}192.25 \\
191.97 \\
.15\end{array}$ & $\begin{array}{r}16.27 \\
16.25 \\
.14\end{array}$ \\
\hline 1.05 & $\begin{array}{c}\text { TA } \\
\text { TD } \\
\text { ERR }\end{array}$ & $\begin{array}{r}4.28 \\
4.28 \\
.18\end{array}$ & $\begin{array}{r}3.36 \\
3.35 \\
.21\end{array}$ & $\begin{array}{l}.82 \\
.82 \\
.15\end{array}$ & $\begin{array}{r}58.74 \\
58.71 \\
.05\end{array}$ & $\begin{array}{r}43.20 \\
48.18 \\
.03\end{array}$ & $\begin{array}{r}2.39 \\
2.39 \\
.02\end{array}$ \\
\hline 1.50 & $\begin{array}{c}\text { TA } \\
\text { TDD } \\
\text { ERR }\end{array}$ & $\begin{array}{r}1.93 \\
1.92 \\
.10\end{array}$ & $\begin{array}{r}1.34 \\
1.34 \\
.15\end{array}$ & $\begin{array}{l}.27 \\
.27 \\
.16\end{array}$ & $\begin{array}{r}10.46 \\
10.46 \\
.03\end{array}$ & $\begin{array}{r}6.00 \\
6.00 \\
.00\end{array}$ & $\begin{array}{l}.29 \\
.29 \\
.00\end{array}$ \\
\hline
\end{tabular}


TABLE 3

Mean of First Overflow Time for $E_{2} / M / 3 / N-1$ System

\begin{tabular}{|c|c|c|c|c|c|c|c|}
\hline \multicolumn{2}{|c|}{$N$} & \multicolumn{3}{|c|}{11} & \multicolumn{3}{|c|}{41} \\
\hline$\rho$ & $\begin{array}{c}x_{0} \\
\text { mean }\end{array}$ & 0 & 5 & 10 & 0 & 20 & 40 \\
\hline 0.70 & $\begin{array}{c}\text { TA } \\
\text { TD } \\
\text { ERR }\end{array}$ & $\begin{array}{r}283.76 \\
221.04 \\
22.10\end{array}$ & $\begin{array}{r}273.47 \\
211.16 \\
22.78\end{array}$ & $\begin{array}{r}112.80 \\
82.89 \\
26.52\end{array}$ & $* * * * *$ & $* * * * *$ & $* * * * *$ \\
\hline 0.75 & $\begin{array}{c}\text { TA } \\
\text { TD } \\
\text { ERR }\end{array}$ & $\begin{array}{r}153.17 \\
132.28 \\
13.64\end{array}$ & $\begin{array}{r}144.77 \\
124.00 \\
14.35\end{array}$ & $\begin{array}{l}53.25 \\
44.02 \\
17.33\end{array}$ & $* * * * *$ & $* * * * *$ & $* * * * *$ \\
\hline 0.80 & $\begin{array}{c}\text { TA } \\
\text { TD } \\
\text { ERR }\end{array}$ & $\begin{array}{r}90.86 \\
84.14 \\
7.39\end{array}$ & $\begin{array}{r}83.83 \\
77.08 \\
8.05\end{array}$ & $\begin{array}{l}27.53 \\
24.73 \\
10.18\end{array}$ & $\begin{array}{r}833445.68 \\
560589.27 \\
32.74\end{array}$ & $\begin{array}{r}831987.08 \\
559236.59 \\
32.78\end{array}$ & $\begin{array}{r}216832.83 \\
139335.39 \\
35.74\end{array}$ \\
\hline 0.85 & $\begin{array}{c}\text { TA } \\
\text { TD } \\
\text { ERR }\end{array}$ & $\begin{array}{r}58.48 \\
56.67 \\
3.11\end{array}$ & $\begin{array}{r}52.48 \\
50.56 \\
3.66\end{array}$ & $\begin{array}{r}15.47 \\
14.69 \\
5.04\end{array}$ & $\begin{array}{r}63679.37 \\
49185.00 \\
22.76\end{array}$ & $\begin{array}{r}63085.13 \\
48644.94 \\
22.89\end{array}$ & $\begin{array}{r}12525.29 \\
9353.98 \\
25.32\end{array}$ \\
\hline 0.90 & $\begin{array}{c}\text { TA } \\
\text { TD } \\
\text { ERR }\end{array}$ & $\begin{array}{r}40.34 \\
40.19 \\
.37\end{array}$ & $\begin{array}{r}35.14 \\
34.85 \\
.82\end{array}$ & $\begin{array}{l}9.38 \\
9.22 \\
1.66\end{array}$ & $\begin{array}{r}6533.74 \\
5949.46 \\
8.94\end{array}$ & $\begin{array}{r}6275.79 \\
5699.54 \\
9.18\end{array}$ & $\begin{array}{r}878.27 \\
783.46 \\
10.79\end{array}$ \\
\hline 0.95 & $\begin{array}{c}\text { TA } \\
\text { TD } \\
\text { ERR }\end{array}$ & $\begin{array}{l}29.48 \\
29.85 \\
-1.25\end{array}$ & $\begin{array}{r}24.90 \\
25.12 \\
-.88\end{array}$ & $\begin{array}{l}6.09 \\
6.11 \\
-.32\end{array}$ & $\begin{array}{r}1142.90 \\
1124.38 \\
1.62\end{array}$ & $\begin{array}{r}1009.15 \\
990.72 \\
1.83\end{array}$ & $\begin{array}{r}93.15 \\
90.96 \\
2.35\end{array}$ \\
\hline 1.05 & $\begin{array}{c}\text { TA } \\
\text { TD } \\
\text { ERR }\end{array}$ & $\begin{array}{l}18.00 \\
18.46 \\
-2.55\end{array}$ & $\begin{array}{l}14.33 \\
14.64 \\
-2.19\end{array}$ & $\begin{array}{r}3.05 \\
3.10- \\
1.67\end{array}$ & $\begin{array}{r}171.75 \\
173.21 \\
-.85\end{array}$ & $\begin{array}{r}117.62 \\
118.20 \\
-.50\end{array}$ & $\begin{array}{l}6.15 \\
6.17 \\
-.29\end{array}$ \\
\hline 1.50 & $\begin{array}{c}\text { TA } \\
\text { TDD } \\
\text { ERR }\end{array}$ & $\begin{array}{r}5.72 \\
5.83 \\
-1.83\end{array}$ & $\begin{array}{l}3.84 \\
3.88 \\
-.97\end{array}$ & $\begin{array}{r}.66 \\
.66 \\
-.25\end{array}$ & $\begin{array}{r}25.71 \\
25.82 \\
-.42\end{array}$ & $\begin{array}{r}14.00 \\
14.00 \\
.00\end{array}$ & $\begin{array}{l}.67 \\
.67 \\
.00\end{array}$ \\
\hline
\end{tabular}


TABLE 4

Mean of First Overflow Time for $E_{2} / M / 7 / N-1$ System

\begin{tabular}{|c|c|c|c|c|c|c|c|}
\hline \multicolumn{2}{|c|}{$N$} & \multicolumn{3}{|c|}{11} & \multicolumn{3}{|c|}{41} \\
\hline$\rho$ & $\begin{array}{c}x_{0} \\
\text { mean }\end{array}$ & 0 & 5 & 10 & 0 & 20 & 40 \\
\hline 0.70 & $\begin{array}{c}\text { TA } \\
\text { TD } \\
\text { ERR }\end{array}$ & $\begin{array}{r}30.49 \\
27.46 \\
9.96\end{array}$ & $\begin{array}{l}28.75 \\
25.65 \\
10.79\end{array}$ & $\begin{array}{l}12.29 \\
10.46 \\
14.89\end{array}$ & $* * * * *$ & $* * * * *$ & $* * * * *$ \\
\hline 0.75 & $\begin{array}{c}\text { TA } \\
\text { TD } \\
\text { ERR }\end{array}$ & $\begin{array}{r}20.15 \\
19.14 \\
5.01\end{array}$ & $\begin{array}{r}18.59 \\
17.53 \\
5.74\end{array}$ & $\begin{array}{l}7.23 \\
6.58 \\
8.95\end{array}$ & $* * * * *$ & $* * * * *$ & $* * * * *$ \\
\hline 0.80 & $\begin{array}{c}\text { TA } \\
\text { TD } \\
\text { ERR }\end{array}$ & $\begin{array}{r}14.24 \\
14.01 \\
1.66\end{array}$ & $\begin{array}{r}12.84 \\
12.55 \\
2.23\end{array}$ & $\begin{array}{l}4.57 \\
4.35 \\
4.62\end{array}$ & $\begin{array}{r}169354.16 \\
1107639.32 \\
36.44\end{array}$ & $\begin{array}{r}169064.07 \\
107385.26 \\
36.48\end{array}$ & $\begin{array}{r}44063.45 \\
26757.02 \\
39.28\end{array}$ \\
\hline 0.85 & $\begin{array}{c}\text { TA } \\
\text { TD } \\
\text { ERR }\end{array}$ & $\begin{array}{r}10.63 \\
10.69 \\
-.50\end{array}$ & $\begin{array}{l}9.36 \\
9.37 \\
-.09\end{array}$ & $\begin{array}{l}3.06 \\
3.01 \\
1.62\end{array}$ & $\begin{array}{r}14418.94 \\
11515.52 \\
20.14\end{array}$ & $\begin{array}{r}14290.89 \\
11395.38 \\
20.26\end{array}$ & $\begin{array}{r}2838.81 \\
2192.54 \\
22.77\end{array}$ \\
\hline 0.90 & $\begin{array}{c}\text { TA } \\
\text { TD } \\
\text { ERR }\end{array}$ & $\begin{array}{r}8.30 \\
8.45 \\
-1.82\end{array}$ & $\begin{array}{r}7.13 \\
7.24 \\
-1.57\end{array}$ & $\begin{array}{l}2.16 \\
2.17 \\
-.33\end{array}$ & $\begin{array}{r}1827.59 \\
1688.06 \\
7.63\end{array}$ & $\begin{array}{r}1762.22 \\
1623.75 \\
8.97\end{array}$ & $\begin{array}{r}247.56 \\
224.09 \\
9.48\end{array}$ \\
\hline 0.95 & $\begin{array}{c}\text { TA } \\
\text { TD } \\
\text { ERR }\end{array}$ & $\begin{array}{r}6.71 \\
6.89 \\
-2.58\end{array}$ & $\begin{array}{r}5.63 \\
5.77 \\
-2.41\end{array}$ & $\begin{array}{r}1.60 \\
1.62 \\
-1.51\end{array}$ & $\begin{array}{r}379.68 \\
375.01 \\
1.23\end{array}$ & $\begin{array}{r}341.32 \\
336.41 \\
1.44\end{array}$ & $\begin{array}{r}32.00 \\
31.37 \\
1.98\end{array}$ \\
\hline 1.05 & $\begin{array}{c}\text { TA } \\
\text { TD } \\
\text { ERR }\end{array}$ & $\begin{array}{l}4.76 \\
4.91 \\
3.12 \\
\end{array}$ & $\begin{array}{r}3.82 \\
3.94 \\
-3.16\end{array}$ & $\begin{array}{r}.97 \\
.99 \\
-2.41 \\
\end{array}$ & $\begin{array}{r}66.32 \\
66.95 \\
-.95\end{array}$ & $\begin{array}{r}48.31 \\
48.59 \\
-.59\end{array}$ & $\begin{array}{l}2.59 \\
2.60 \\
-.34\end{array}$ \\
\hline 1.50 & $\begin{array}{c}\text { TA } \\
\text { TDD } \\
\text { ERR }\end{array}$ & $\begin{array}{r}1.98 \\
2.02 \\
-2.18\end{array}$ & $\begin{array}{r}1.39 \\
1.42 \\
-2.22 \\
\end{array}$ & $\begin{array}{r}.27 \\
.28 \\
-1.01 \\
\end{array}$ & $\begin{array}{r}10.53 \\
10.58 \\
-.46 \\
\end{array}$ & $\begin{array}{r}6.00 \\
6.00 \\
.00 \\
\end{array}$ & $\begin{array}{l}.29 \\
.29 \\
.00\end{array}$ \\
\hline
\end{tabular}


TABLE 5

Mean of First Overflow Time for $H_{2} / M / 3 / N-1$ System

\begin{tabular}{|c|c|c|c|c|c|c|c|}
\hline \multicolumn{2}{|c|}{$N$} & \multicolumn{3}{|c|}{11} & \multicolumn{3}{|c|}{41} \\
\hline$\rho$ & $\underset{\text { mean }}{x_{0}}$ & 0 & 5 & 10 & 0 & 20 & 40 \\
\hline 0.70 & $\begin{array}{c}\text { TA } \\
\text { TD } \\
\text { ERR }\end{array}$ & $\begin{array}{r}78.39 \\
70.97 \\
9.46\end{array}$ & $\begin{array}{r}71.32 \\
64.49 \\
9.57\end{array}$ & $\begin{array}{r}22.94 \\
20.71 \\
9.72\end{array}$ & $\begin{array}{r}684085.65 \\
559578.57 \\
18.20\end{array}$ & $\begin{array}{r}682739.14 \\
558405.29 \\
18.21\end{array}$ & $\begin{array}{r}175185.24 \\
142999.36 \\
18.94\end{array}$ \\
\hline 0.75 & $\begin{array}{c}\text { TA } \\
\text { TD } \\
\text { ERR }\end{array}$ & $\begin{array}{r}54.50 \\
50.21 \\
7.88\end{array}$ & $\begin{array}{r}48.42 \\
44.58 \\
7.91\end{array}$ & $\begin{array}{r}14.36 \\
13.24 \\
7.78\end{array}$ & $\begin{array}{r}90902.59 \\
80808.93 \\
11.10\end{array}$ & $\begin{array}{r}90306.92 \\
80262.35 \\
11.12\end{array}$ & $\begin{array}{r}19189.73 \\
16953.64 \\
11.65\end{array}$ \\
\hline 0.80 & $\begin{array}{c}\text { TA } \\
\text { TD } \\
\text { ERR }\end{array}$ & $\begin{array}{r}39.83 \\
37.16 \\
6.71\end{array}$ & $\begin{array}{r}34.51 \\
32.21 \\
6.66\end{array}$ & $\begin{array}{l}9.50 \\
8.90 \\
6.30\end{array}$ & $\begin{array}{r}15955.54 \\
14785.95 \\
7.33\end{array}$ & $\begin{array}{r}15651.25 \\
14500.87 \\
7.35\end{array}$ & $\begin{array}{r}2674.27 \\
2469.16 \\
7.67\end{array}$ \\
\hline 0.85 & $\begin{array}{c}\text { TA } \\
\text { TD } \\
\text { ERR }\end{array}$ & $\begin{array}{r}30.35 \\
28.58 \\
5.83\end{array}$ & $\begin{array}{r}25.64 \\
24.18 \\
5.71\end{array}$ & $\begin{array}{l}6.59 \\
6.25 \\
5.17\end{array}$ & $\begin{array}{r}3649.46 \\
3478.28 \\
4.69\end{array}$ & $\begin{array}{r}3476.27 \\
3313.50 \\
4.68\end{array}$ & $\begin{array}{r}462.95 \\
440.68 \\
4.81\end{array}$ \\
\hline 0.90 & $\begin{array}{c}\text { TA } \\
\text { TD } \\
\text { ERR }\end{array}$ & $\begin{array}{r}23.94 \\
22.70 \\
5.16\end{array}$ & $\begin{array}{r}19.73 \\
18.75 \\
4.96\end{array}$ & $\begin{array}{l}4.78 \\
4.57 \\
4.28\end{array}$ & $\begin{array}{r}1103.99 \\
1070.86 \\
3.00\end{array}$ & $\begin{array}{r}995.56 \\
966.61 \\
2.91\end{array}$ & $\begin{array}{r}101.14 \\
98.25 \\
2.87\end{array}$ \\
\hline 0.95 & $\begin{array}{c}\text { TA } \\
\text { TD } \\
\text { ERR }\end{array}$ & $\begin{array}{r}19.44 \\
18.54 \\
4.63\end{array}$ & $\begin{array}{r}15.64 \\
14.96 \\
4.37\end{array}$ & $\begin{array}{l}3.59 \\
3.46 \\
3.58\end{array}$ & $\begin{array}{r}440.62 \\
431.77 \\
2.01\end{array}$ & $\begin{array}{r}367.05 \\
360.55 \\
1.77\end{array}$ & $\begin{array}{r}28.69 \\
28.24 \\
1.59\end{array}$ \\
\hline 1.05 & $\begin{array}{c}\text { TA } \\
\text { TD } \\
\text { ERR }\end{array}$ & $\begin{array}{r}13.74 \\
13.21 \\
3.87\end{array}$ & $\begin{array}{r}10.57 \\
10.20 \\
3.49\end{array}$ & $\begin{array}{r}2.23 \\
2.17 \\
2.57\end{array}$ & $\begin{array}{r}136.61 \\
135.07 \\
1.13\end{array}$ & $\begin{array}{r}95.94 \\
95.36 \\
.60\end{array}$ & $\begin{array}{r}5.28 \\
5.26 \\
.35\end{array}$ \\
\hline 1.50 & $\begin{array}{c}\text { TA } \\
\text { TDD } \\
\text { ERR }\end{array}$ & $\begin{array}{l}5.39 \\
5.27 \\
2.29\end{array}$ & $\begin{array}{l}3.63 \\
3.57 \\
1.65\end{array}$ & $\begin{array}{l}.64 \\
.64 \\
.72\end{array}$ & $\begin{array}{r}25.32 \\
25.18 \\
.54\end{array}$ & $\begin{array}{r}14.00 \\
13.99 \\
.01\end{array}$ & $\begin{array}{l}.67 \\
.67 \\
.00\end{array}$ \\
\hline
\end{tabular}


TABLE 6

Mean of First Overflow Time for $H_{2} / M / 7 / N-1$ System

\begin{tabular}{|c|c|c|c|c|c|c|c|}
\hline \multicolumn{2}{|c|}{$N$} & \multicolumn{3}{|c|}{11} & \multicolumn{3}{|c|}{41} \\
\hline$\rho$ & $\begin{array}{c}x_{0} \\
\text { mean }\end{array}$ & 0 & 5 & 10 & 0 & 20 & 40 \\
\hline 0.70 & $\begin{array}{c}\text { TA } \\
\text { TD } \\
\text { ERR }\end{array}$ & $\begin{array}{r}14.51 \\
13.32 \\
8.17\end{array}$ & $\begin{array}{c}12.89 \\
11.76 \\
8.71\end{array}$ & $\begin{array}{l}4.38 \\
3.98 \\
9.03\end{array}$ & $\begin{array}{r}137422.92 \\
114324.89 \\
16.81\end{array}$ & $\begin{array}{r}137156.32 \\
114088.58 \\
16.82\end{array}$ & $\begin{array}{r}35194.35 \\
29013.17 \\
17.56\end{array}$ \\
\hline 0.75 & $\begin{array}{c}\text { TA } \\
\text { TD } \\
\text { ERR }\end{array}$ & $\begin{array}{r}11.13 \\
10.35 \\
7.02\end{array}$ & $\begin{array}{l}9.66 \\
8.93 \\
7.54\end{array}$ & $\begin{array}{l}3.07 \\
2.84 \\
7.62\end{array}$ & $\begin{array}{r}21211.53 \\
18883.06 \\
10.98\end{array}$ & $\begin{array}{r}21076.36 \\
18759.00 \\
11.00\end{array}$ & $\begin{array}{r}4479.52 \\
3963.31 \\
11.52\end{array}$ \\
\hline 0.80 & $\begin{array}{c}\text { TA } \\
\text { TD } \\
\text { ERR }\end{array}$ & $\begin{array}{l}8.85 \\
8.30 \\
6.14 \\
\end{array}$ & $\begin{array}{l}7.51 \\
7.02 \\
6.63\end{array}$ & $\begin{array}{l}2.25 \\
2.10 \\
6.51\end{array}$ & $\begin{array}{r}4223.30 \\
3928.36 \\
6.98\end{array}$ & $\begin{array}{r}4146.74 \\
3856.46 \\
7.00\end{array}$ & $\begin{array}{r}709.24 \\
657.36 \\
7.31 \\
\end{array}$ \\
\hline 0.85 & $\begin{array}{c}\text { TA } \\
\text { TD } \\
\text { ERR }\end{array}$ & $\begin{array}{l}7.25 \\
6.85 \\
5.45\end{array}$ & $\begin{array}{l}6.02 \\
5.67 \\
5.92 \\
\end{array}$ & $\begin{array}{l}1.70 \\
1.61 \\
5.64\end{array}$ & $\begin{array}{r}1089.69 \\
1040.37 \\
4.53\end{array}$ & $\begin{array}{r}1041.93 \\
994.91 \\
4.51\end{array}$ & $\begin{array}{r}139.27 \\
132.82 \\
4.63\end{array}$ \\
\hline 0.90 & $\begin{array}{c}\text { TA } \\
\text { TD } \\
\text { ERR }\end{array}$ & $\begin{array}{l}6.08 \\
5.78 \\
4.90 \\
\end{array}$ & $\begin{array}{l}4.95 \\
4.69 \\
5.34 \\
\end{array}$ & $\begin{array}{l}1.33 \\
1.27 \\
4.94\end{array}$ & $\begin{array}{r}365.21 \\
354.40 \\
2.96\end{array}$ & $\begin{array}{r}332.99 \\
323.44 \\
2.87\end{array}$ & $\begin{array}{r}34.16 \\
33.21 \\
2.80\end{array}$ \\
\hline 0.95 & $\begin{array}{c}\text { TA } \\
\text { TD } \\
\text { ERR }\end{array}$ & $\begin{array}{l}5.21 \\
4.97 \\
4.45\end{array}$ & $\begin{array}{l}4.16 \\
3.95 \\
4.87 \\
\end{array}$ & $\begin{array}{l}1.07 \\
1.02 \\
4.37\end{array}$ & $\begin{array}{r}157.38 \\
154.20 \\
2.02\end{array}$ & $\begin{array}{r}134.19 \\
131.77 \\
1.80\end{array}$ & $\begin{array}{r}10.68 \\
10.52 \\
1.59\end{array}$ \\
\hline 1.05 & $\begin{array}{c}\text { TA } \\
\text { TD } \\
\text { ERR }\end{array}$ & $\begin{array}{l}4.00 \\
3.85 \\
3.77\end{array}$ & $\begin{array}{l}3.08 \\
2.95 \\
4.15\end{array}$ & $\begin{array}{r}.74 \\
.71 \\
3.49\end{array}$ & $\begin{array}{r}52.88 \\
52.27 \\
1.17\end{array}$ & $\begin{array}{r}38.96 \\
38.69 \\
.69\end{array}$ & $\begin{array}{r}2.20 \\
2.19 \\
.39\end{array}$ \\
\hline 1.50 & $\begin{array}{c}\text { TA } \\
\text { TDD } \\
\text { ERR }\end{array}$ & $\begin{array}{l}1.89 \\
1.84 \\
2.26\end{array}$ & $\begin{array}{l}1.30 \\
1.27 \\
2.49\end{array}$ & $\begin{array}{r}.26 \\
.25 \\
1.60\end{array}$ & $\begin{array}{r}10.38 \\
10.33 \\
.54\end{array}$ & $\begin{array}{r}6.00 \\
5.99 \\
.02\end{array}$ & $\begin{array}{l}.29 \\
.29 \\
.00\end{array}$ \\
\hline
\end{tabular}




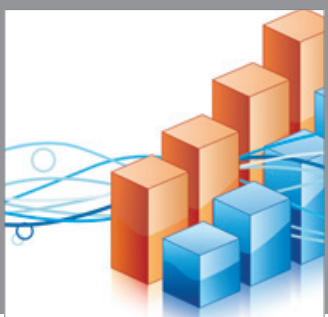

Advances in

Operations Research

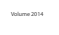

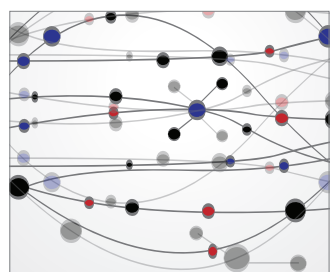

\section{The Scientific} World Journal
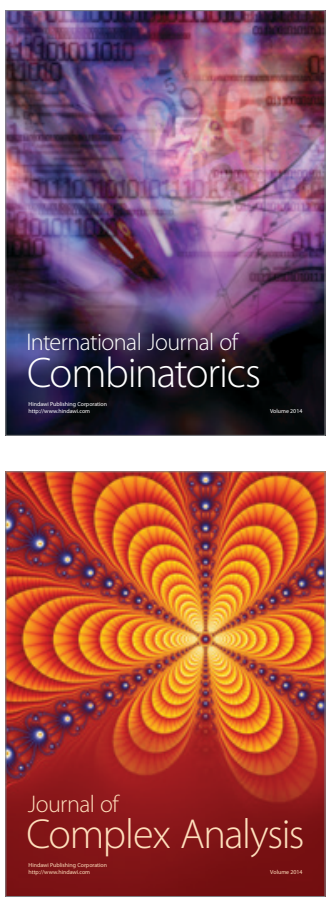

International Journal of

Mathematics and

Mathematical

Sciences
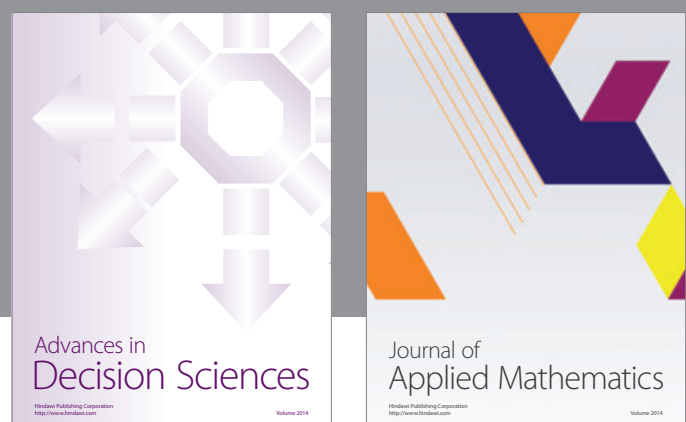

Journal of

Applied Mathematics
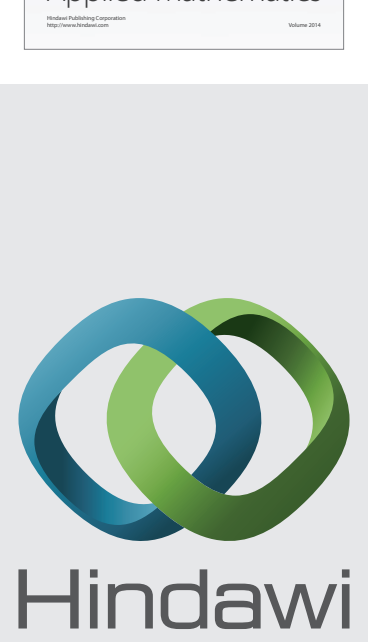

Submit your manuscripts at http://www.hindawi.com
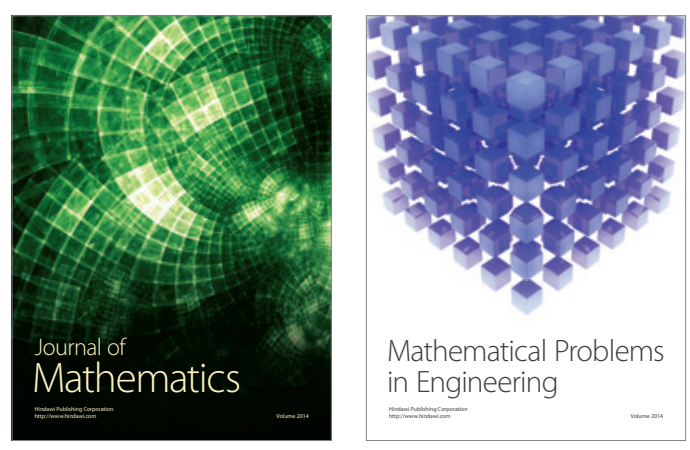

Mathematical Problems in Engineering
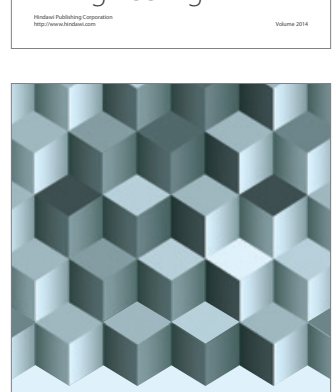

Journal of

Function Spaces
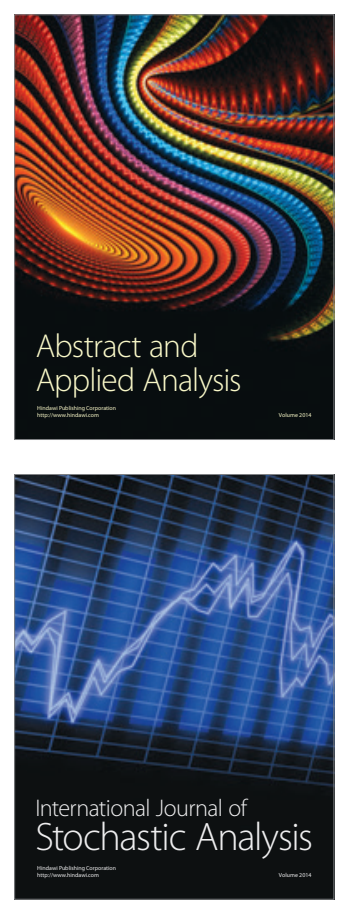

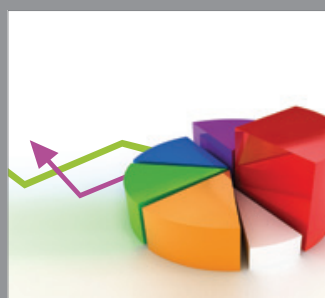

ournal of

Probability and Statistics

Promensencen
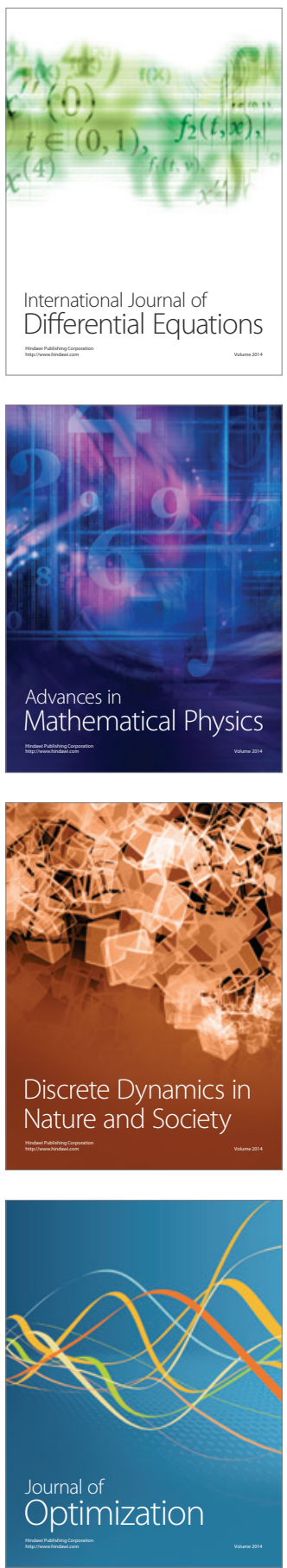